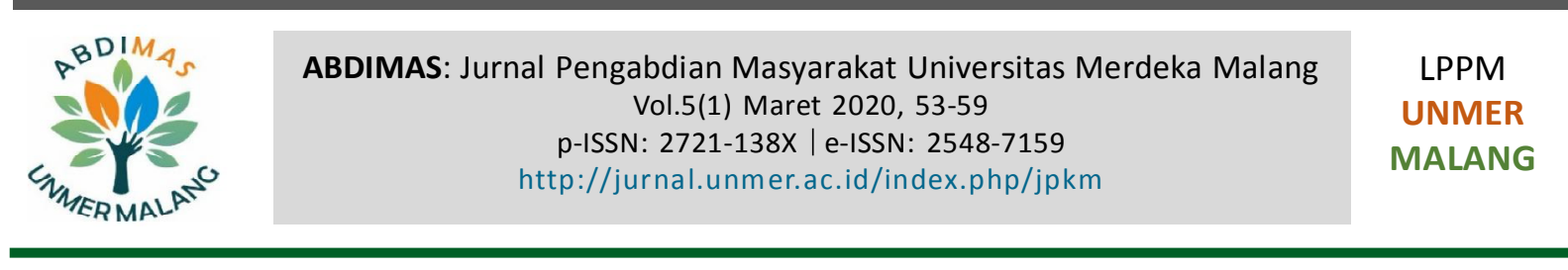

\title{
Sosialisasi dan FGD Penanggulangan Perdagangan Orang pada Masyarakat Raman Utara Kabupaten Lampung Timur
}

\author{
Mashuril Anwar, Maroni Maroni, Erna Dewi, Rini Fathonah \\ Fakultas Hukum, Universitas Lampung, \\ Jl. Prof. Dr. Ir. Sumantri Brojonegoro, Lampung, 35141, Indonesia
}

\section{ARTICLE INFO:}

Received: 2019-09-03

Revised: 2020-01-28

Accepted: 2020-02-24

\section{Keywords:}

Countermeasures;

FGD, Human

trafficking; North Raman;

Socialization

\begin{abstract}
In general, the people of North Raman District do not yet know and understand correctly about tackling trafficking. The people of North Raman Subdistrict have never received legal counsel regarding the crime of trafficking. Therefore, it is necessary to provide good knowledge and understanding through socialization and focus group discussions (FGD) to overcome the problems of partners related to the handling of trafficking in people in the North Raman Regency, East Lampung Regency. Efforts made in this activity are by providing knowledge and understanding of the law about tackling trafficking in people in the District of North Raman, East Lampung Regency. Then proceed with discussion and question and answer, and test the understanding of participants by giving a pre test and post test. The results of the activities show that the socialization activities and focus group discussions (FGD) are important to be carried out in order to increase knowledge, understanding and awareness of the legal community regarding tackling trafficking.
\end{abstract}

(c) 2020 Published by University of Merdeka Malang This is an open access article distributed under the CC BY-SA 4.0 license (https://creativecommons.org/licenses/by-sa/4.0/)

How to cite: Anwar, M., Maroni, M., Dewi, E., \& Fathonah, R. (2020). Sosialisasi dan FGD penanggulangan perdagangan orang pada masyarakat Raman Utara Kabupaten Lampung Timur. Abdimas: Jurnal Pengabdian Masyarakat Universitas Merdeka Malang, 5(1), 53-59. https://doi.org/10.26905/abdimas.v5i1.3367

\section{PENDAHULUAN}

Tindak pidana perdagangan orang adalah bentuk modern dari perbudakan manusia. Tindak pidana perdagangan orang juga merupakan salah satu bentuk perlakuan terburuk dari pelanggaran harkat dan martabat manusia. Bertambah maraknya tindak pidana perdagangan orang di berbagai negara, termasuk Indonesia dan negara-negara berkembang lainnya, telah menjadi perhatian Indonesia sebagai bangsa, masyarakat internasional dan anggota organisasi internasional, terutama Perserikatan Bangsa-Bangsa (PBB). Berdasarkan bukti empiris, perempuan dan anak adalah kelompok yang paling banyak menjadi korban tindak pidana perdagangan orang. Korban diperdagangkan tidak hanya untuk tujuan pelacuran atau bentuk eksploitasi seksual lainnya, tetapi juga mencakup bentuk eksploitasi lain, misalnya kerja paksa atau pelayanan paksa, perbudakan atau praktek serupa perbudakan itu (Widiastuti, 2010).

$\square$ Corresponding Author:

Mashuril Anwar:

Tel. +62 721701609

E-mail: mashurilanwar97@gmail.com 
ABDIMAS: Jurnal Pengabdian Masyarakat Universitas Merdeka Malang

Volume 5, No 1, Maret 2020:53-59

Pelaku tindak pidana perdagangan orang melakukan perekrutan, pengangkutan, pemindahan, penyembunyian atau penerimaan orang untuk tujuan menjebak, menjerumuskan atau memanfaatkan orang tersebut dalam praktek eksploitasi dengan segala bentuknya dengan ancaman kekerasan, penggunaan kekerasan, penculikan, pemalsuan, penipuan, penyalahgunaan kekuasaan atau posisi rentan atau memberi bayaran atau manfaat sehingga memperoleh persetujuan dari orang yang memegang kendali atas korban. Perdagangan manusia terutama perdagangan anak-anak merupakan suatu bentuk perbudakan dan suatu kejahatan terorganisasi (organized crimes) dan tersistematis (Wijayanto, 2014; Daud \& Sopoyono, 2019; Salamor, 2019). Perbudakan dalam kesadaran dan keyakinan moral manusia, yang merupakan bentuk pelanggaran terhadap hak asasi manusia. Sebagai bentuk kejahatan terorganisasi (organized crimes), perdagangan manusia cenderung melintasi batas-batas antar negara atau yang dikenal transnational organized crime, disamping tindak kejahatan lainnya seperti narkotika dan psikotropika, penyelundupan imigran, penyelundupan senjata, pencucian uang dan sebagainya (Wangga, 2010). Perdagangan orang merupakan bentuk kejahatan yang resikonya rendah namun besar perolehan keuntungannya (Mahrus \& Pranomo, 2011). Sifat kejahatannya yang sangat sistematis dan mekanisme-mekanisme canggih yang digunakan berpadu dengan kenyatan masih banyaknya negara yang belum memiliki hukum atau peraturan perundangundangan sebagai instrumen untuk memberantas kejahatan ini.

Persoalan perdagangan orang saat ini telah menjadi suatu keprihatinan bagi dunia internasional. Hak asasi manusia (HAM) dianggap sebagai penyebab sekaligus akibat dari perdagangan orang. Pelanggaran HAM yang dimaksud seperti kerja paksa, eksploitasi seksual dan tenaga kerja, kekerasan, serta perlakuan sewenang-wenang terhadap para korbannya. Para pelaku perdagangan orang secara licik telah mengeksploitasi kemiskinan, memanipulasi harapan dan kepolosan dari para korbannya dengan menggunakan ancaman, intimidasi dan kekerasan untuk membuat para korban menjalani perhambaan paksa, menjalani peonage, menjalani perhambaan karena hutang (debt bondage), dan perkawinan paksa atau palsu, terlibat dalam pelacuran terpaksa atau untuk bekerja dibawah kondisi yang sebanding dengan perbudakan untuk keuntungan pedagang. Korban tidak lagi diperlakukan seperti manusia, melainkan selayaknya budak yang dipaksa untuk memproduksi barang-barang murah ataupun memberikan layanan yang terus menerus. Mereka hidup dalam ketakutan dan banyak juga yang pada akhirnya menjadi korban kekerasan.

Anak salah satu korban yang mendominasi dalam perdagangan orang, hal ini disebabkan karena kondisi anak yang belum matang baik fisik maupun mental seringkali dimanfaatkan oleh oknum perdagangan orang untuk diperdagangkan. Bila dilihat secara aturan legal, terdapat banyak jaminan perlindungan bagi anak dari perdagangan. Selain dalam Konvensi Hak Anak (CRC) yang telah diratifikasi oleh Indonesia, terdapat sedikitnya 4 instrumen internasional lain yang mengatur tentang trafficking atau perdagangan anak (dan perempuan), dan 4 instrumen nasional yaitu UU Kesejahteraan Anak, UU Hak Asasi Manusia, UU Perlindungan Anak, dan UU Hukum Pidana (HukumOnline, 2019). Pasal 76F Undang-Undang No. 35 Tahun 2014 tentang Perlindungan Anak menyatakan bahwa "Setiap orang dilarang menempatkan, membiarkan, melakukan, menyuruh melakukan, atau turut serta melakukan penculikan, penjualan, atau perdagangan anak. Ketentuan sanksinya dapat kita lihat dalam Pasal 83 UU Perlindungan Anak yang menyatakan:

"Setiap orang yang melanggar ketentuan sebagaimana dimaksud dalam Pasal 76F dipidana dengan pidana penjara paling singkat 3 (tiga) tahun dan paling lama 15 (lima belas) tahun dan denda paling sedikit Rp60.000.000,00 (enam puluh juta rupiah) dan paling banyak Rp300.000.000,00 (tiga ratus juta rupiah)." 


\section{Sosialisasi dan FGD Penanggulangan Perdagangan Orang pada Masyarakat Raman Utara...}

Mashuril Anwar, Maroni Maroni, Erna Dewi, Rini Fathonah

Perdagangan anak akhir-akhir ini menjadi persoalan dan mendapat sorotan di Indonesia. Hal ini tidak lepas dari maraknya kasus tindak pidana perdagangan anak di Indonesia, bahkan Indonesia dinyatakan menempati urutan terburuk di dunia bersama dengan beberapa negara lain di Asia dalam hal perdagangan anak dan perempuan. Bahkan beberapa lembaga donor telah memberi pernyataan akan menghentikan bantuannya jika Indonesia tidak dapat segera memperbaiki kondisi tersebut (hukumonline, 2019). Beberapa penelitian yang terkait upaya pencegahan terhadap perdagangan orang dari segi hukum telah banyak dilakukan (Wijayanto, 2014; Purnama, Dermawan, \& Mahyudin, 2019; Salamor, 2019). Salah satu kasus perdagangan anak yang masih hangat di ingatan kita yakni kasus perdagangan anak di Kecamatan Raman Utara Kabupaten Lampung Timur. Kasus tersebut terungkap setelah Jajaran Kepolisian Resort (Polres) Lampung Timur berhasil mengamankan dua orang pelaku berinisial PI (36) dan BA (21) yang merupakan warga Desa Ratna Daya, Kecamatan Raman Utara, yang diduga melakukan bisnis perdagangan anak dibawah umur, di wilayah hukum Lampung Timur, Kamis (10/01/19). Dari data pihak kepolisian, kedua pelaku mempekerjakan tiga orang perempuan dibawah umur, bahkan masih berstatusnya pelajar. "Para korban di jajakan kepada laki-laki hidung belang, untuk menjadi Pekerja Seks Komersial (PSK) dengan diiming-imingi imbalan uang yang cukup besar, sejak bulan Desember 2018 lalu”, ujar Kapolres Lampung Timur AKBP Taufan Dirgantoro, didampingi Kapolsek Raman Utara IPTU Rahadi. Masih dikatakan Rohadi, dari penangkapan terhadap kedua pelaku, polisi berhasil mengamankan ketiga korban yang di jadikan Eksploitasi Seksual tersebut. Sebut saja Mawar (16), Melati (16) dan Bunga (15), yang merupakan warga masyarakat Kabupaten Lampung Timur (penalampungnews, 2019). Selain kasus tersebut, masih banyak lagi kasunys perdagangan orang yang melibatkan perempuan dan anak sebagai korbannya.

Banyak ahli mengatakan bahwa perdagangan anak merupakan persoalan yang gampang-gampang susah. Salah satunya penanggulangan perdagangan anak ini harus dilakukan dengan cara pendekatan komprehensif, yaitu penegakan hukum dan penegakan kapasitas masyarakat (Wangga \& Silvya, (2010); Effendi, 2013). Cara penanggulangan ini juga diakui bahwa penanggulangan perdagangan anak harus dihentikan dengan pendekatan yang tepat melalui pemberian informasi akan bahaya perdagangan anak kepada masyarakat dan aparat-aparat desa. Dalam mewujudkan upaya penanggulangan perdagangan anak, harus melibatkan banyak pihak yaitu penegak hukum, masyarakat sipil, media, serta negara transit dan negara tujuan migran. Selain upaya tersebut, upaya pemerintah yang tak kalah penting adalah kepedulian terhadap penuntasan kemiskinan. Seperti yang diketahui bahwa kemiskinan merupakan faktor utama penyebab terjadinya perdagangan orang termasuk anak.

Anak sebagai bagian dari generasi muda merupakan tunas dan penerus cita-cit bangsa yang memiliki peran strategis dan mempunyai ciri dan sifat khusus. Selain itu anak merupakan sumber daya manusia yang sangat potensial bagi pembangunan nasional. Oleh karena itu, dalam rangka menciptakan sumber daya manusia yang berkualitas, diperlukan pelayanan dan perlindungan terhadap anak dari segala bentuk kejahatan termasuk perdagangan orang. Ada banyak cara untuk membantu pemerintah mencegah dan menanggulangi tindak pidana perdagangan orang salah satunya dengan mengadaka kegiatan-kegiatan sosialisasi guna memberikan wawasan dan pemahaman kepada masyarakat mengenai tindak pidana perdagangan anak.

Berdasarkan uraian di atas, mengenai tindak Perdagangan orang yang semakin marak, terutama yang melibatkan anak sebagai korbannya, dalam upaya untuk memberikan pemahaman dan arahan kepada masyarakat dalam penanggulangannya baik secara penal maupun non penal, perlu dilakukan sosialisasi dan Focus Group Discussion (FGD) penanggulangan perdagangan orang (trafficking) pada masyarakat Raman Utara Kabupaten Lampung Timur. 
ABDIMAS: Jurnal Pengabdian Masyarakat Universitas Merdeka Malang

Volume 5, No 1, Maret 2020:53-59

\section{METODE}

Kegiatan ini dilakukan dengan menggunakan metode ceramah, diskusi dan tanya jawab. Penggunaan metode ceramah sabanyak $50 \%$, diskusi $25 \%$ dan tanya jawab $25 \%$. Metode ini digunakan agar materi yang disampaikan mudah dipahami oleh peserta. Selain itu, untuk menguji pemahaman peserta juga diberikan soal pre test dan post test. Tim menyampaikan materi dengan cara ceramah dengan menggunakan LCD yang sudah disiapkan sebelumnya, peserta sangat antusias dan serius menyimak serta memperhatikan dan mendengarkan dengan seksama di dalam kegiatan penyuluhan hukum ini. Kemudian dilanjutkan dengan diskusi dan tanya jawab antara peserta dengan pemateri mengenai penanggulangan perdagangan orang pada masyarakat Raman Utara Kabupaten Lampung Timur.

Secara keseluruhan kegiatan Sosialisasi dan Focus Group Discussion (FGD) Penanggulangan Perdagangan Orang (Trafficking) Pada Masyarakat Raman Utara Kabupaten Lampung Timur ini dilaksanakan melalui tahapan-tahapan sebagai berikut ini : (1) Tahap Persiapan, persiapan dilakukan selama 10 hari dengan kegiatan mempersiapkan administrasi kegiatan seperti surat perizinan dan perlengkapan lainnya, menggandakan materi kegiatan, daftar pertanyaan, peninjauan ke lokasi kegiatan termasuk pula pendekatan sosial kepada Kepolisan Resort Lampung Timur, Camat Raman Utara dan masyarakat Kecamatan Raman Utara. (2) Tahap Pelaksanaan, kegiatan penyuluhan ini dilakukan selama 1 hari dengan ketentuan awal kegiatan yaitu: Melaksanakan evaluasi awal (Pre-Test), Penyampaian materi kegiatan, Diskusi dan tanya jawab, Melaksanakan evaluasi akhir (Post-Test). (3) Tahap Akhir, selama 19 hari dengan kegiatan evaluasi akhir, penyusunan dan penggandaan laporan kegiatan, penyerahan laporan hasil kegiatan, perbaikanperbaikan ke Lembaga Pengabdian kepada Masyarakat Universitas Lampung.

\section{HASIL DAN PEMBAHASAN}

\section{Hasil}

Pengabdian kepada masyarakat ini lebih menitikberatkan kemampuan dari warga masyarakat Kecamatan Raman Utara dalam mencegah dan menanggulangi tindak pidana perdagangan orang. Khalayak sasaran yang hadir dalam kegiatan ini berjumlah 108 orang yang terdiri dari warga masyarakat dan aparat pemerintahan desa se-Kecamatan Raman Utara. Sebagian besar dari masyarakat Kecamatan Raman Utara bekerja sebagai petani, sehingga pemahaman mereka tentang tindak pidana perdagangan orang masih simpang siur dan maya apalagi menyangkut hak-hak korban. Berdasarkan hasil evaluasi awal, proses dan akhir terhadap khlayak sasaran peserta kegiatan ini berhasil dengan baik.

Tabel 1. Perbandingan pra penyampaian materi dan pasca penyampaian materi Sosialisasi dan Focus Group Discussion (FGD) Penanggulangan Perdagangan Orang (Trafficking)

\begin{tabular}{lll}
\hline \multicolumn{1}{c}{ Unsur } & \multicolumn{1}{c}{ Pra Penyampaian Materi } & \multicolumn{1}{c}{ Pasca Penyampaian Materi } \\
\hline $\begin{array}{l}\text { Perdagangan Orang dan } \\
\text { Pencegahannya }\end{array}$ & Belum memahami perdagangan orang & $\begin{array}{l}\text { Sudah memahami perdagangan orang } \\
\text { (trafficking) dan cara mencegahnya }\end{array}$ \\
$\begin{array}{l}\text { Perlindungan hukum terhadap dan cara mencegahnya } \\
\text { korban TPPO }\end{array}$ & Belum memahami perlindungan hukum & $\begin{array}{l}\text { Sudah memahami dan mengerti bentuk } \\
\text { Penanggulangan TPPO }\end{array}$ \\
& terhadap korban TPPO & perlindungan hukum terhadap korban TPPO \\
& Belum memahami dan belum mengerti & Sudah memahami dan mengerti bagaimana \\
& cara penanggulangan TPPO & cara menanggulangi TPPO \\
\hline
\end{tabular}




\section{Sosialisasi dan FGD Penanggulangan Perdagangan Orang pada Masyarakat Raman Utara...}

Mashuril Anwar, Maroni Maroni, Erna Dewi, Rini Fathonah

Berdasarkan Tabel 1, hasil evaluasi awal mengenai pengetahuan dan pemahaman masyarakat tentang tindak pidana perdagangan orang, menunjukan bahwa masyarakat belum sepenuhnya mengetahui dan memahami tindak pidana perdagangan orang, instrumen hukum yang mengaturnya, perlindungan hukum korban perdagangan orang dan penanggulangan tindak pidana perdagangan orang. Sebelum dilakukan penyampain materi, pada intinya masyarakat hanya mengetahui bahwa perdagangan orang adalah kejahatan, namun mereka belum mengetahui dan memahami bagaimana penanggulangannya. Hal ini dapat dilihat dari hasil pre-test yang dilakukan, dimana $70 \%$ masyarakat Kecamatan Raman Utara belum memahami pengertian perdagangan orang. Dari hasil pretest, ditemukan 50\% warga masyarakat menjawab bahwa penyebab terjadinya perdagangan orang adalah (1) Kemiskinan (2) Rendahnya pendidikan, (3) Minimnya lapangan pekerjaan, (4) Bebasnya mengakses internet, (5) Kurangnya pengawasan orangtua, (6) Pergaulan bebas, (7) Minimnya pengetahuan dan pemahaman nilai-nilai agama, (8) Lingkungan yang buruk.

\section{Tahapan pelaksanaan}

\section{Sosialisasi}

Pengetahuan masyarakat tentang cara melakukan pencegahan dan penanggulangan perlindungan hukum korban perdagangan orang, $80 \%$ warga Kecamatan Raman Utara tidak mengetahuinya, apalagi mengenai sanksi, aturan, hak-hak korban dan modus operandi pelaku. Berdasarkan hasil pre-test, selama ini upaya penanggulangan tindak pidana perdagangan orang di Kecamatan Raman Utara hanya dilakukan sebatas pemberian himbauan untuk waspada dan sosialiasi ke masyarakat.

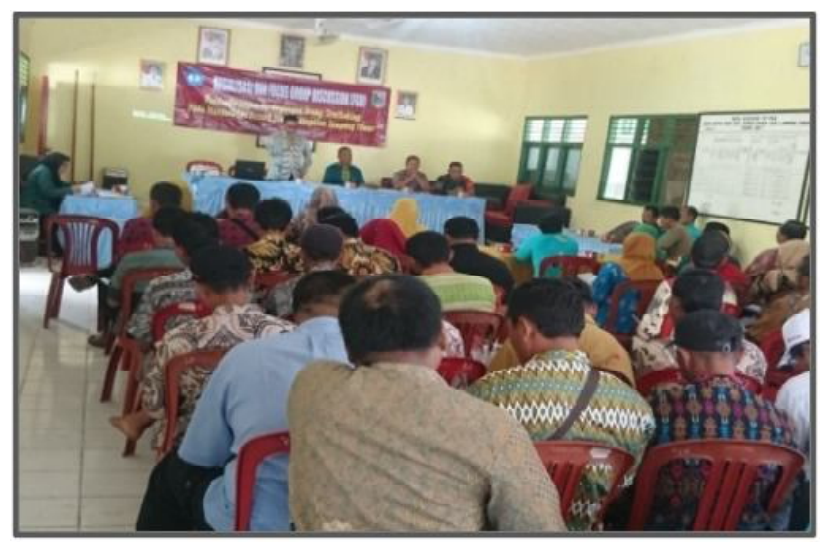

Gambar 1. Kegiatan sosialisasi

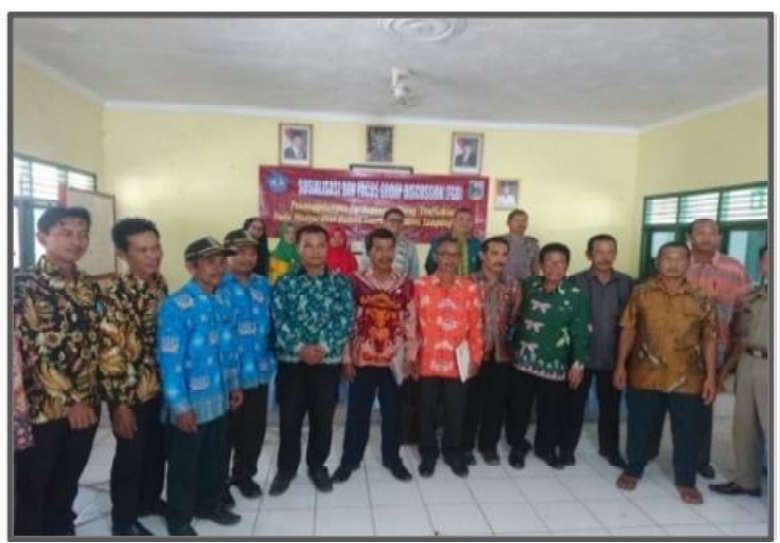

Gambar 2. Sesi foto bersama

Pentingnya pencegahan dan penanggulangan perlindungan hukum korban perdagangan manusia harus disosialisasikan agar memahami dan mampu mengkategorikan yang termasuk perdagangan manusia dan yang bukan.

Kegiatan sosialisai ditutup dengan membahas hasil pre-test, memberi wawasan yang jelas dan menyimpulkan hasil sosialisasi untuk menjadi wacana bagi warga.

Berdasarkan hasil evaluasi akhir, dapat diketahui bahwa telah ada peningkatan pengetahuan dan pemahaman hukum masyarakat Kecamatan Raman Utara mengenai tindak pidana perdagangan orang. 
ABDIMAS: Jurnal Pengabdian Masyarakat Universitas Merdeka Malang

Volume 5, No 1, Maret 2020: 53-59

Secara perlahan masyarakat mulai memahami apa itu perdagangan manusia, sebab terjadinya perdagangan manusia, hak-hak korban, cara pencegahan dan penanggulannya.

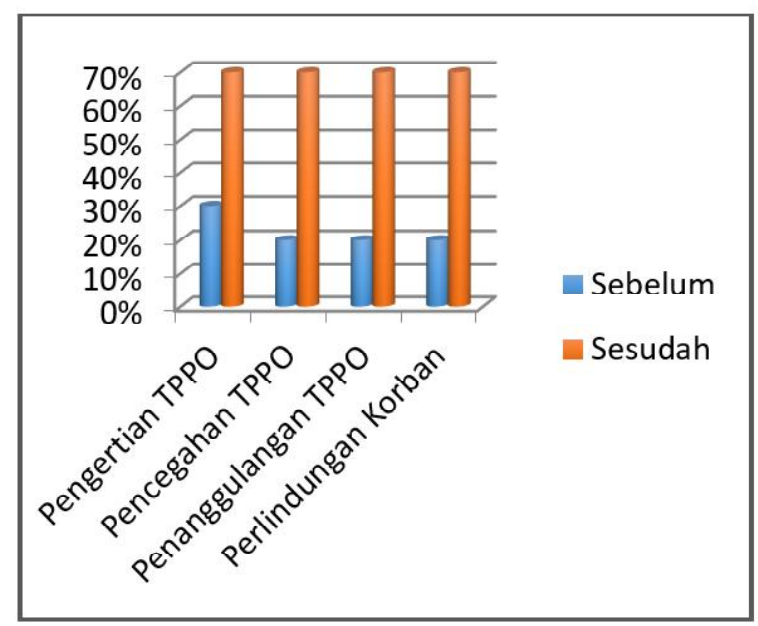

Gambar 3. Hasil pengolahan bahan

Berdasarkan hasil pertanyaan post-test (Gambar 3), tingkat pemahaman masyarakat mengenai tindak pidana perdagangan orang meningkat menjadi $70 \%$. Seluruh peserta merasa puas karena materi yang disampaikan sangat jelas, mudah dipahami dan bermanfaat. Dari hasil pertanyaan post-test dapat diketahui juga bahwa 90\% masyarakat kecamatan Raman Utara terkesan senang dan menanggap bahwa kegiatan sangat perlu dilakukan untuk menambah pengetahuan dan menginginkan kegiatan sosialisasi dan focus group discussion (FGD) penanggulangan perdagangan orang (trafficking) dilakukan kembali. Kemudian sebagian besar masyarakat juga menyarankan agar kegiatan ini dilakukan kepada setiap dusun seperti kelompok pengajian, organisasi kepemudaan, calon TKI dan anak-anak.

\section{SIMPULAN DAN SARAN}

\section{Simpulan}

Kegiatan sosialisasi dan focus group discussion (FGD) penanggulangan perdagangan orang (trafficking) pada masyarakat Raman Utara Kabupaten Lampung Timur telah memberikan pengetahuan dan pemahaman kepada masyarakat mengenai penanggulangan perdagangan orang. Hal ini dapat dilihat dari hasil evaluasi, bahwa ada peningkatan pengetahuan dan pemahaman hukum masyarakat Kecamatan Raman Utara mengenai tindak pidana perdagangan orang. Secara perlahan masyarakat mulai memahami apa itu perdagangan manusia, sebab terjadinya perdagangan manusia, hak-hak korban, cara pencegahan dan penanggulannya. Keberhasilan kegiatan ini karena adanya dukungan dan antusiasme masyarakat peserta untuk mengetahui cara penanggulangan tindak pidana perdagangan orang. Selain itu, dari hasil pertanyaan post-test dapat diketahui juga bahwa 90\% masyarakat kecamatan Raman Utara terkesan senang dan menanggap bahwa kegiatan sangat perlu dilakukan untuk menambah pengatahuan dan menginginkan kegiatan Sosialisasi dan Focus Group Discussion (FGD) 
Sosialisasi dan FGD Penanggulangan Perdagangan Orang pada Masyarakat Raman Utara...

Mashuril Anwar, Maroni Maroni, Erna Dewi, Rini Fathonah

\section{Saran}

Perlu adanya sosialisasi penanggulangan perdagangan orang (trafficking) dilakukan kembali agar kegiatan ini dilakukan di setiap dusun.

\section{DAFTAR PUSTAKA}

Daud, B. S., \& Sopoyono, E. (2019). Penerapan sanksi pidana terhadap pelaku perdagangan manusia (human trafficking) di Indonesia. Jurnal Pembangunan Hukum Indonesia, 1(3), 352-365. https://doi.org/10.14710/jphi.v1i3.352-365

Effendi, E. (2013). Pemberantasan perdagangan orang dengan sarana hukum pidana. Jurnal Cita Hukum, 1(1), 85-100. https://doi.org/10.15408/jch.v1i1.2982

Mahrus, A., \& Pranomo, B. A. (2011). Perdagangan Orang: Dimensi Instrumen Internasional dan Pengaturannya di Indonesia. Bandung: PT. Citra Aditya Bakti.

Purnama, C., Dermawan, W., \& Mahyudin, E. (2019). Sosialisasi mengenai perdagangan manusia (human trafficking) dalam upaya pencegahan Tindak Pidana Perdagangan Orang (TPPO) di Kecamatan Tempuran Kabupaten Karawang. Kumawula: Jurnal Pengabdian Kepada Masyarakat, 1(2), 90. https://doi.org/10.24198/kumawula.v1i2.19794

Salamor, Y. B. (2019). Penanggulangan tindak pidana perdagangan orang di Maluku. Jurnal Muara IImu Sosial, Humaniora, dan Seni, 2(2), 511. https://doi.org/10.24912/jmishumsen.v2i2.938

Wangga, M. S. E. (2010). Pencegahan dan pemberantasan tindak pidana perdagangan perempuan dan anak di Indonesia. Jurnal Hukum Prioris, 2(4), 230-244.

Widiastuti, T. W. (2010). Upaya pencegahan tindak pidana perdagangan orang (trafficking). Jurnal Wacana Hukum, IX(1), 107-120.

Wijayanto, D. E. (2014). Perlindungan hukum atas tindak pidana perdagangan orang melalui UU No. 21 Tahun 2007 Tentang Tindak Pidana Perdagangan Orang. Jurnal Independent, 2(2), 13. https://doi.org/10.30736/ji.v2i2.23 